\title{
Intake, apparent nutrient digestibility and ingestive behavior of sheep fed cashew nut meal $^{1}$
}

\author{
Patrícia Guimarães Pimentel ${ }^{2}$, Elzânia Sales Pereira ${ }^{3}$, Augusto César de Queiroz ${ }^{4}$, Ivone \\ Yurika Mizubuti ${ }^{5}$, José Gilson Louzada Regadas Filho ${ }^{6}$, lana Sérvulo Gomes Maia ${ }^{7}$
}

\author{
1 Pesquisa parcialmente financiada pelo Programa de Desenvolvimento Científico e Tecnológico Regional, FUNCAP/CNPq. \\ 2 Departamento de Zootecnia, UFC, Fortaleza-CE. Bolsista DCR-FUNCAP/CNPq. \\ ${ }^{3}$ Departamento de Zootecnia, UFC, Fortaleza-CE. Pesquisador do CNPq. \\ ${ }^{4}$ Departamento de Zootecnia, UFV, Viçosa-MG. Pesquisador do CNPq. \\ 5 Departamento de Zootecnia, UEL, Londrina-PR. Pesquisador do CNPq. \\ ${ }^{6}$ Programa de Pós-graduação em Zootecnia - UFC. Bolsista FUNCAP. \\ 7 Graduação em Zootecnia - UFC. Bolsista IC/CNPq.
}

ABSTRACT - The objective of this work was to evaluate intake, nutrient apparent digestibility and ingestive behavior of sheep fed rations with cashew nut meal (CNM) at the levels of $0 ; 10 ; 20$ and 30\% in the concentrate ration. It was used a double $4 \times 4$ Latin square experimental design. Intakes of dry matter (DM), organic matter, crude protein, mineral matter, non-fibrous carbohydrates and total digestible nutrients were not influenced by the addition of CNM, however, intake of neutral detergent fiber (NDF), acid detergent fiber and total carbohydrates presented a quadratic behavior with the increase of content of lipids in the ration. Apparent digestibility of DM, organic matter, crude protein, NDF, acid detergent fiber and non-fibrous carbohydrates was not influenced by the addition of CNM in the rations; however digestibility of ether extract and total carbohydrates presented quadratic and linear behavior, respectively. It was not observed any significant differences in time spent with feeding and rumination, however, total chewing time was influenced, presenting increasing linear behavior with the levels of CNM. Concerning to intakes of dry matter and NDF per hour, feed efficiency and rumination were not affected by increase on lipid content in the rations. Ruminating chews time per rumen bolus, number of ruminated boli and the number of ruminating chews per day were not influenced by experimental rations. In sheep feeding management, it is suggested as a feeding alternative the use of up to $30 \%$ of CNM in the concentrate ration if it is available.

Key Words: byproduct, chewing activity, lipids, Santa Inês sheep

\section{Consumo, digestibilidade aparente dos nutrientes e comportamento ingestivo em ovinos alimentados com farelo de castanha de caju}

\begin{abstract}
RESUMO - Objetivou-se avaliar o consumo, a digestibilidade aparente dos nutrientes e o comportamento ingestivo de ovinos alimentados com rações contendo farelo de castanha de caju (FCC) nos níveis de 0; 10; 20 e 30\% na ração concentrada. O delineamento experimental utilizado foi quadrado latino $4 \times 4$ duplo. Os consumos de matéria seca (MS), matéria orgânica, proteína bruta, matéria mineral, carboidratos não-fibrosos e nutrientes digestíveis totais não foram influenciados pela adição de FCC, contudo o consumo de fibra em detergente neutro (FDN), fibra em detergente ácido e carboidratos totais apresentaram comportamento quadrático com o aumento no teor de lipídeos da ração. A digestibilidade aparente da MS, matéria orgânica, proteína bruta, FDN, fibra em detergente ácido e carboidratos não fibrosos não foi influenciada pela adição de FCC nas rações, contudo as digestibilidades do extrato etéreo e dos carboidratos totais apresentaram comportamentos quadrático e linear, respectivamente. Não foram observadas diferenças significativas no tempo despendido com alimentação e ruminação, no entanto, o tempo de mastigação total foi influenciado, apresentando comportamento linear crescente com os níveis de FCC. As eficiências de alimentação e ruminação não foram influenciadas pelo aumento no teor de lipídeos das rações, no que se refere aos consumos de MS e FDN por hora. O tempo de mastigação merícica por bolo ruminal, o número de bolos ruminados e o número de mastigações merícicas por dia não foram influenciados pelas rações experimentais. No manejo alimentar de ovinos, caso haja disponibilidade, recomenda-se como alternativa alimentar a utilização de no máximo 30\% de FCC na ração concentrada.
\end{abstract}

Palavras-chave: atividade mastigatória, lipídeos, ovinos Santa Inês, subproduto 


\section{Introduction}

Dietary lipids are found mainly in non-esterified form as galactolipids (forage) and triglycerides (oil seed). Except for the grains, most foods used in the formulation of ruminant diets contain low level of lipids, with values ranging from 1 to $4 \%$ in dry matter (Van Soest, 1994). Palmquist \& Jenkins (1980) suggested that inclusion of lipids in diets for ruminant must be limited to $5 \%$ of total dry matter inasmuch as the microorganisms have no physiological mechanisms to digest lipids in addition to promote changes in the rumen fermentation pattern (Cenkvári et al., 2005). The main mechanisms involved in this process include physical coating of the fiber, the surfactant effects on the microbial membrane, and the reduction in cations availability due to the formation of calcium soaps. Vegetable oils, rich in unsaturated fatty acids may promote negative effects in the rumen and in the digestibility of fibrous material.

In northeastern Brazil, among the agro-industrial byproducts from the cashew crop, there is the cashew nut meal (CNM) produced in a large scale during the dry season in the region. The addition of the cashew nut meal as lipid source allows the higher energy content in the rations, reduces the risk of rumen acidosis and allows better productive and reproductive performance of animals (Pimentel et al., 2007).

Thus, the present study evaluated the intake, the apparent digestibility of nutrients and ingestive behavior of sheep fed rations containing different levels of inclusion of cashew nut meal.

\section{Material and Methods}

This experiment was carried out in the Setor de Ovinocaprinocultura of Departamento de Zootecnia at Universidade Federal do Ceará, Fortaleza - CE. It was used eight non-castrated male Santa Ines sheep at approximately 20 months of age and with average weight of $25 \mathrm{~kg}$, confined in metabolism cages, with feeders and drinkers. Firstly, the animals were weighed, identified with earrings, treated against ecto and endoparasites and supplemented with injectable A vitamin. The animals were distributed into four groups with different levels of inclusion of cashew nut meal $(0 ; 10 ; 20$ and $30 \%$ of dry matter) in the concentrate ration and arranged in $4 \times 4$ double Latin square design.

The experiment lasted 64 days, divided into four 16-day experimental periods in which 10 days were for adaptation and six days for data collection. The rations were prepared according to NRC (2007) and contained Tifton 85 hay as roughage (Tables 1 and 2).

The animals were fed ad libitum once a day (7:00 a.m) and the orts were previously weighed to determine the daily intake. The amount of feed was calculated to permit orts corresponding to 5 to $10 \%$. Animals had always easy access to water.

Table 2 - Proximate and chemical composition of rations containing cashew nut meal

\begin{tabular}{|c|c|c|c|c|}
\hline \multirow[t]{2}{*}{ Ingredient (\%DM) } & \multicolumn{4}{|c|}{ Level of cashew nut meal } \\
\hline & $0 \%$ & $10 \%$ & $20 \%$ & $30 \%$ \\
\hline Tifton 85 hay & 60.00 & 60.00 & 60.00 & 60.00 \\
\hline Cashew nut meal & 0.00 & 3.82 & 7.67 & 11.52 \\
\hline Ground corn & 18.00 & 16.20 & 14.40 & 12.60 \\
\hline Soybean meal & 13.20 & 11.88 & 10.56 & 9.22 \\
\hline Wheat bran & 7.20 & 6.47 & 5.76 & 5.03 \\
\hline Dicalcium phosphate & 0.16 & 0.22 & 0.28 & 0.34 \\
\hline Limestone & 1.04 & 0.98 & 0.92 & 0.86 \\
\hline Salt & 0.24 & 0.24 & 0.24 & 0.24 \\
\hline Premix $^{1}$ & 0.16 & 0.16 & 0.16 & 0.16 \\
\hline \multicolumn{5}{|l|}{ Nutrient (\%DM) } \\
\hline Dry matter & 89.90 & 90.38 & 90.30 & 90.38 \\
\hline Crude protein & 14.31 & 14.51 & 14.55 & 14.13 \\
\hline Ether extract & 2.97 & 4.35 & 5.95 & 7.78 \\
\hline Ash & 7.39 & 7.64 & 7.83 & 7.87 \\
\hline Neutral detergent fiber & 49.96 & 48.78 & 48.47 & 48.26 \\
\hline Acid detergent fiber & 26.67 & 26.64 & 26.55 & 26.25 \\
\hline Total carbohydrate & 75.33 & 73.51 & 71.67 & 70.23 \\
\hline Non-fibrous carbohydrate & 25.37 & 24.72 & 23.20 & 21.96 \\
\hline Total digestible nutrient & 61.87 & 61.45 & 59.50 & 61.82 \\
\hline
\end{tabular}

1 Calcium - 7.5\%; phosphorus - 3.0\%; iron - 16,500 ppm; manganese 9,750 ppm; zinc - 35,000 ppm; iodine - 1,000 ppm; selenium - $225 \mathrm{ppm}$; cobalt $-1,000 \mathrm{ppm}$.

Table 1 - Bromatological composition of Tifton 85 hay, cashew nut meal (CNM) and experimental concentrates

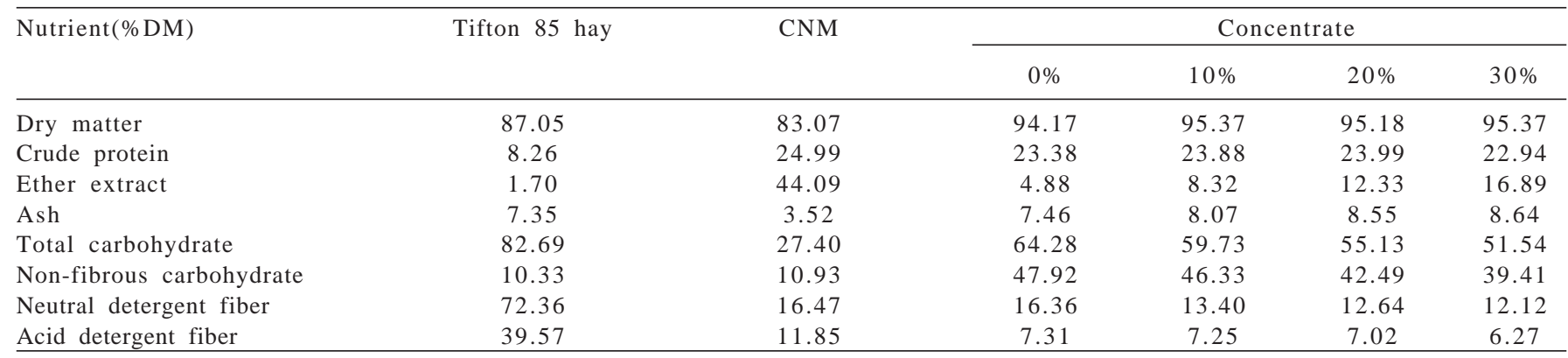


In order to determine the digestibility of the dry matter $(\mathrm{DM})$, organic matter $(\mathrm{OM})$, crude protein (CP), ether extract (EE), neutral detergent fiber (NDF), acid detergent fiber (ADF), total carbohydrate (TC) and non-fibrous carbohydrate (NFC), samples of feces were collected from the $10^{\text {th }}$ to the $15^{\text {th }}$ day of each period, in the morning and in the afternoon, and formed samples of animal/treatment/period. The estimation of fecal output was obtained by using the indigestible acid detergent fiber (iADF) as an indicator. Samples of feces, supplied food and orts were incubated in rumen environment for 144 hours, as described by Cochran et al. (1986).

Samples of supplied food, orts and feces were placed in plastic bags properly identified and stored at $-20^{\circ} \mathrm{C}$ for subsequent laboratory analyses. At the end of the experiment, samples of offered rations, orts and feces were thawed at room temperature and compounded by animal/ treatment/period. The pre-drying of these samples were carried out in a forced ventilation oven at $55^{\circ} \mathrm{C}$ for 72 hours and then grinded using a $1-\mathrm{mm}$ screen, then placed in plastic containers with lids and stored for determination of DM, ash, OM, CP and EE, according to Silva \& Queiroz (2002), and the NDF and ADF as proposed by Van Soest et al. (1991). The intake of total digestible nutrients was obtained according the recommendation by Sniffen et al. (1992). The percentage of NFC in the rations was calculated following the equation proposed by NRC (2001): NFC $=100-(\% C P$ + \%NDF + \%EE + \%Ash). The content of total carbohydrate was obtained as described by Sniffen et al. (1992).

For the measurement of ingestive behavior, the animals were submitted to visual observation on the $15^{\text {th }}$ and $16^{\text {th }}$ days of each experimental period. In the first day of observation, the animals were evaluated during three 2-hour periods (8:00 a.m. to 10:00 a.m.; 2:00 p.m. to 4:00 p.m.; and 6:00 p.m. to 8:00 p.m.) to collect data and to estimate the number of ruminating chews per bolus and the time spent of ruminating chews per bolus, by using digital stopwatch. On the second day, the ingestive behavior was determined visually at intervals of five minutes for 24 hours to determine the time spent eating and ruminating (Johnson \& Combs, 1991). During the conduction of the experiment, the environment was kept under artificial light at night.

The variables referring to ingestive behavior were taken from the relationships:

$\mathrm{FE}=\mathrm{DMI} / \mathrm{ET} ; \mathrm{RE}=\mathrm{DMI} / \mathrm{RUT} ; \mathrm{RE}=\mathrm{CMFDN} / \mathrm{RUT}$; $\mathrm{TCT}=\mathrm{TF}+\mathrm{RUT} ; \mathrm{BOL}=\mathrm{RUT} / \mathrm{MM}_{\mathrm{tb}} ;$ No.MM/day $=$ BOLMM $_{\mathrm{nb}}$; where: $\mathrm{FE}(\mathrm{gDM} / \mathrm{h}, \mathrm{gNDF} / \mathrm{h})=$ feeding efficiency; $\operatorname{DMI}(\mathrm{gDM} /$ day $)=$ dry matter intake; ET (h/day) = eating time; $\mathrm{RE}(\mathrm{gDM} / \mathrm{h}, \mathrm{gNDF} / \mathrm{h})=$ rumination efficiency; $\mathrm{RUT}(\mathrm{h} /$ day $)=$ ruminating time; TCT $(\mathrm{h} /$ day $)=$ total chewing time; $\mathrm{BOL}$ $\left(\mathrm{N}^{\mathrm{o}} / \mathrm{day}\right)=$ number of ruminate boli; $\mathrm{MM}_{\mathrm{tb}}$ (sec/bolus $)=$ time of ruminating chew per bolus; No.MM/day = number of ruminating chews per day and $\mathrm{MM}_{\mathrm{nb}}\left(\mathrm{N}^{0} /\right.$ /bolus $)=$ number of ruminating chews per bolus (Polli et al., 1996).

The variables were submitted to analysis of variance and regression analysis by using the software SAEG System of Statistical and Genetic Analysis (UFV, 2000).

\section{Results and Discussion}

Dry matter intake of the animals was not influenced $(\mathrm{P}>0.05)$ by the inclusion levels of cashew nut meal in the rations in any of the regarded forms (Table 3). According to Mertens (1987), the DM intake is related to the meeting of energy requirements; however the levels of ether extract of rations were below $8 \%$, level established by NRC (2001) as a limit from which reductions would occur in the DM intake.

The intake of organic matter, crude protein, ash, non-fibrous carbohydrates and total digestible nutrients were not influenced by the levels of inclusion of lipids

Table 3 - Nutrient intake by Santa Ines sheep fed rations containing cashew nut meal

\begin{tabular}{|c|c|c|c|c|c|c|c|}
\hline \multirow[t]{2}{*}{ Item } & \multicolumn{4}{|c|}{ Level of cashew nut meal } & \multicolumn{3}{|c|}{ Regression parameter } \\
\hline & $0 \%$ & $10 \%$ & $20 \%$ & $30 \%$ & Equation & $r^{2}$ & $\mathrm{P}$ \\
\hline Dry matter (g/day) & 1004.29 & 1027.05 & 941.40 & 794.24 & $\tilde{Y}=941.75$ & - & ns \\
\hline Dry matter $\left(\mathrm{g} / \mathrm{BW}^{0.75}\right)$ & 0.082 & 0.084 & 0.077 & 0.065 & $\underset{\widetilde{Y}}{\tilde{Y}}=0.077$ & - & ns \\
\hline Organic matter (g/day) & 835.70 & 858.07 & 785.13 & 661.79 & $\underset{\sim}{\tilde{Y}}=785.17$ & - & ns \\
\hline Crude protein (g/day) & 152.68 & 159.44 & 145.96 & 120.13 & $\tilde{Y}=144.55$ & - & ns \\
\hline Neutral detergent fiber (g/day) & 453.77 & 449.49 & 411.69 & 340.99 & $\hat{Y}=453.80+1.22 X-0.17 X^{2}$ & 0.99 & 0.0014 \\
\hline Neutral detergent fiber (\% BW) & 1.61 & 1.60 & 1.45 & 1.23 & $\hat{Y}=1.61+0.003 X-0.0005 X^{2}$ & 0.99 & 0.0401 \\
\hline Neutral detergent fiber (g/BW $\left.{ }^{0.75}\right)$ & 37.05 & 36.82 & 33.49 & 28.14 & $\hat{Y}=37.11+0.08 X-0.01 X^{2}$ & 0.99 & 0.0302 \\
\hline Acid detergent fiber (g/day) & 246.69 & 251.68 & 231.28 & 193.00 & $\hat{Y}=247.07+1.43 X-0.11 X^{2}$ & 0.99 & 0.0247 \\
\hline Total carbohydrate (g/day) & 745.65 & 740.64 & 659.91 & 489.48 & $\underset{\sim}{\hat{Y}}=744.95+3.92 X-0.41 X^{2}$ & 0.99 & 0.0120 \\
\hline Non-fibrous carbohydrate (g/day) & 291.88 & 291.14 & 248.22 & 200.10 & $\underset{\sim}{\tilde{Y}}=257.84$ & - & ns \\
\hline
\end{tabular}


either. The intake of ether extract presented linear behavior, as shown in the equation $Y=32.76+1.29 X$ (Table 3), so for every $1 \%$ addition of cashew nut meal, the intake of ether extract increased $1.29 \mathrm{~g}$.

The consumption of neutral detergent fiber was influenced by the inclusion of cashew nut meal inasmuch as it decreased as levels of lipids in the diet increased. The rations were calculated so that the fiber was not a limiting factor for the consumption. The mean consumption of fiber in the rations with 20 and $30 \%$ of cashew nut meal were lower than those found by Branco et al. (2010) and Carvalho et al. (2006), who did not verify repletion effect in the average intake of fiber (1.24 and 1.53\% BW, respectively). The intake of ADF and total carbohydrate presented quadratic behavior. One major effect of lipid inclusion in ruminant diets is the interference on ruminal fermentation, which causes reductions in the digestibility of the fiber. The mechanisms by which the lipid supplementation reduce the voluntary intake, despite of not being well elucidated, involve both effects on ruminal fermentation and intestinal motility and also on the ration palatability.

The apparent digestibility of dry matter, organic matter, crude protein, neutral detergent fiber, acid detergent fiber and non-fibrous carbohydrate was not influenced by the addition of cashew nut meal in the diet (Table 4). These results corroborate the results obtained by Bateman II \& Jenkins (1998), who did not observe any effects of the inclusion of lipids on the apparent digestibility of these nutrients, suggesting that significant amounts of unprotected lipids may be added to the rations inasmuch as they do not affect the nutrient digestibility. However, the digestibility of ether extract and total carbohydrates presented quadratic and linear behavior, respectively $(\mathrm{P}<0.05$; Table 4). In agreement with Silva et al. (2007), one major effect of lipid inclusion in ruminant diets is its interference in rumen fermentation, reducing the nutrient digestibility, especially fiber. In this study, the rations were prepared to maintain the same level of protein and NDF, changing only ether extract. Thus, it is assumed that the conditions of the rumen environment were kept constant and had no influence on the fiber digestibility, even at the maximum level of inclusion of the byproduct.

According to the NRC (2001), the digestibility of fatty acid, a component of ether extract, can be influenced by the dry matter intake, by the amount consumed, and by the characteristics of dietary lipids. The degree of unsaturation is perhaps the feature that most influence lipid digestion. Therefore, the optimal source of lipids for ruminants would be the one that does not interfere on digestibility of other nutrients and produce high intestinal digestibility. Although presenting $78.7 \%$ of unsaturated fatty acid, the cashew nut meal did not influence on nutrient digestibility, except total carbohydrate. Thus, Pimentel (2007) reported that oleic acid (57.4\% of total fatty acids) may not interfere on the rumen environment much.

Ingestive behavior was not affected by the inclusion of cashew nut meal, concerning the time spent eating and ruminating, in minutes per day. The chewing activity has been one of the most studied and used measures to evaluate the effectiveness of the fiber, because of their effect on saliva production, the process of grinding the food, DM intake, ruminal variables and the fat percentage in the milk (Mertens, 2001). The time spent by animals in chewing activity in the present study had an increasing linear effect. According to the linear equation obtained: $\hat{Y}=839.13+$ $0.44 \mathrm{X}$, for every $1 \%$ addition of cashew nut meal, the animal increased by 0.44 minutes the time spent chewing (Table 5).

Likewise, the minutes spent to ruminate $1.0 \mathrm{~g}$ of DM influenced chewing activity (min/gDM). The variables presented quadratic behavior, respectively ranging from 0.57 to 0.78 and from 0.83 to $1.11 \mathrm{~min} / \mathrm{gDM}$ for the diets without cashew nut meal and for that with $30 \%$ of this byproduct. However, the intake, rumination and chewing activity were not different $(\mathrm{P}>0.05)$ among the rations with cashew nut meal, when considered in minutes spent per gram of neutral detergent fiber consumed.

Table 4 - Apparent digestibility of nutrients of rations containing cashew nut meal in Santa Ines sheep

\begin{tabular}{|c|c|c|c|c|c|c|c|}
\hline \multirow[t]{2}{*}{ Item } & \multicolumn{4}{|c|}{ Level of cashew nuts } & \multicolumn{3}{|c|}{ Regression parameter } \\
\hline & $0 \%$ & $10 \%$ & $20 \%$ & $30 \%$ & Equation & $r^{2}$ & $\mathrm{P}$ \\
\hline Dry matter (\%) & 63.13 & 61.22 & 57.10 & 59.30 & $\tilde{\mathrm{Y}}=60.19$ & - & ns \\
\hline Crude protein (\%) & 75.25 & 75.53 & 72.98 & 72.59 & $\tilde{Y}=74.09$ & - & ns \\
\hline Ether extract (\%) & 59.47 & 64.13 & 72.04 & 82.32 & $\hat{Y}=59.42+0.34 X+0.14 X^{2}$ & 0.99 & 0.0221 \\
\hline Total carbohydrate (\%) & 62.40 & 59.71 & 53.72 & 47.11 & $\hat{\mathrm{Y}}=63.52-0.52 \mathrm{X}$ & 0.96 & 0.0076 \\
\hline Non-fibrous carbohydrate (\%) & 78.17 & 70.64 & 66.06 & 69.07 & $\tilde{Y}=70.99$ & - & ns \\
\hline
\end{tabular}

ns $=$ not significant. 
Table 5 - Time spent in the intake, ruminating and total chewing in sheep fed rations containing cashew nut meal

\begin{tabular}{|c|c|c|c|c|c|c|c|}
\hline \multirow[t]{2}{*}{ Item } & \multicolumn{4}{|c|}{ Level of cashew nut meal } & \multicolumn{3}{|l|}{ Regression parameter } \\
\hline & $0 \%$ & $10 \%$ & $20 \%$ & $30 \%$ & Equation & $r^{2}$ & $\mathrm{P}$ \\
\hline & \multicolumn{4}{|c|}{ Intake } & & & \\
\hline Minutes/gDM & 0.26 & 0.26 & 0.28 & 0.33 & $\underset{\widetilde{Y}}{\tilde{Y}}=0.28$ & - & ns \\
\hline \multirow[t]{2}{*}{ Minutes/gNDF } & 0.58 & 0.58 & 0.59 & 0.76 & $\tilde{Y}=0.63$ & - & ns \\
\hline & \multicolumn{4}{|c|}{ Rumination } & & & \\
\hline \multirow[t]{2}{*}{ Minutes/gNDF } & 1.29 & 1.29 & 1.38 & 1.82 & $\tilde{Y}=1.45$ & - & ns \\
\hline & & Chewin & activity & & & & \\
\hline Minutes/day & 840.00 & 841.25 & 850.00 & 851.88 & $\hat{Y}=839.13+0.44 X$ & 0.86 & 0.0245 \\
\hline Minutes/gDM & 0.83 & 0.83 & 0.92 & 1.11 & $\underset{\sim}{\stackrel{P}{P}}=0.83-0.0049 \mathrm{X}+0.0005 \mathrm{X}^{2}$ & 0.99 & 0.0035 \\
\hline Minute/gNDF & 1.86 & 1.87 & 1.97 & 2.58 & $\tilde{Y}=2.07$ & - & ns \\
\hline
\end{tabular}

ns = not significant.

The intake of dry matter can be a direct reflection of the genetic potential of the animal (Allen, 2000) inasmuch as coordinated actions encompass homeostatic and homeorhetic directions, contributing for the achievement or maintenance of an energy profile (long-term regulation). Nevertheless, meals are conducted daily and, at short intervals, the ingestive behavior is surrounded by external stimuli and the initial part of the digestive tract (Mertens, 1996). Accordingly Dulphy \& Demarquilly (1994) reported that, through different mechanisms, each food or ingested ration promote responses from systems of hunger/satiety, which will reflect in meals with varying sizes in the normal circadian cycle of the animal. In the circadian cycle, there are alternations between periods of rest and rumination. Thus, for each food/ration there is a specific feeding model that varies according to the dietary characteristics. The decrease in digestibility may cause an increase in the chewing activity and in the time spent ruminating, to the detriment of the time spent ingesting foods, causing an increase on energy expenditure to complete this process.
The efficiencies of feeding and rumination were not influenced by the increase in the lipid content in the rations inasmuch as there were no variations in the intake of DM and NDF per hour (Table 6).

According to Van Soest (1994), feed daily intake can be described by the number of meals consumed per day, by the duration of the meals and the feeding rate, i.e., the speed at which each meal is made. These processes originate from a complex interaction between the metabolism of the animal and the physical and chemical properties of the diet, and the determinants of food intake by the animal. Furthermore, the amount of ingested food can vary from 40 to $60 \%$ due to the effect of factors inherent to the animal, from 20 to $30 \%$ due to the food, and from 10 to $15 \%$ due to conditions of management and environment. In the present study, the animals were fed once a day. Because ruminant animals have a daily pattern of feeding, both in pasture and in confinement, the time of food distribution, the amount supplied and the frequency of supply may influence the timing of maximal occurrence of ingestive activity. The feeding activities are concentrated in discrete periods and

Table 6 - Feeding behavior of sheep fed rations containing cashew nut meal

\begin{tabular}{|c|c|c|c|c|c|c|c|}
\hline \multirow[t]{2}{*}{ Variable } & \multicolumn{4}{|c|}{ Level of cashew nut meal } & \multicolumn{3}{|c|}{ Regression parameter } \\
\hline & $0 \%$ & $10 \%$ & $20 \%$ & $30 \%$ & Equation & $r^{2}$ & $\mathrm{P}$ \\
\hline \multicolumn{8}{|l|}{ Feeding efficiency } \\
\hline gNDF/hour & 106.99 & 108.10 & 103.46 & 82.08 & $\tilde{\mathrm{Y}}=100.16$ & - & ns \\
\hline \multicolumn{8}{|l|}{ Rumination efficiency } \\
\hline gDM/hour & 104.95 & 105.17 & 94.08 & 79.74 & $\underset{\tilde{Y}}{\tilde{Y}}=95.99$ & - & ns \\
\hline MMnb (No./bolus) ${ }^{2}$ & 55.02 & 61.66 & 63.62 & 61.41 & $\underset{\sim}{\hat{\sim}}=55.04+0.88 X-0.022 X^{2}$ & 0.99 & 0.0085 \\
\hline Ruminated boli (number/day) & 783.62 & 729.01 & 764.97 & 720.93 & $\underset{\sim}{\mathrm{Y}}=749.63$ & - & ns \\
\hline Ruminating chews (number/day) & 43.300 .26 & 44.641 .37 & 48.137 .12 & 44.369 .93 & $\mathrm{Y}=45.112 .17$ & - & ns \\
\hline
\end{tabular}


distributed unevenly throughout the diel cycle. In general, the number and duration of meals are more variable than the period of rumination. By adjusting the number of daily meals and their size (duration vs. ingestion rate), the animals can adjust their consumption in the short term (Grant \& Albright, 1995).

The fiber content and the physical properties of the diet are the main factors affecting rumination time. Because fiber contents were similar among rations, the ruminating efficiency (in gNDF/hour) was not influenced because the number of ruminating periods increases according to the fiber content in the ration.

The chewing time per ruminal bolus, the number of ruminated boli and the number of ruminating chews per day were not influenced by the experimental rations $(\mathrm{P}>0.05)$ whereas the number of ruminating chews per bolus presented quadratic behavior.

\section{Conclusions}

The use of cashew nut meal, when it is available, with a maximum stake of $30 \%$ of concentrate ration, is recommended for feeding management of sheep.

\section{Acknowledgements}

The authors are grateful to the Fundação Cearense de Apoio ao Desenvolvimento Científico e Tecnológico (FUNCAP) and the Conselho Nacional de Desenvolvimento Científico e Tecnológico (CNPq) for granting the scholarship and partial funding of this work through the Programa de Desenvolvimento Científico e Tecnológico Regional, FUNCAP/CNPq.

\section{References}

ALLEN, M.S. Effects of diet on short-term regulation of feed intake by lactating dairy cattle. Journal of Dairy Science, v.83, n.7, p.1598-1624, 2000.

BATEMAN II, H.G.; JENKINS, T.C. Influence of soybean oil in high fiber diets fed to nonlactating cows on ruminal unsaturated fatty acids and nutrient digestibility. Journal of Dairy Science, v.81, n.9, p.2451-2458, 1998.

BRANCO, R.H.; RODRIGUES, M.T.; SILVA, M.M.C. et al. Efeito dos níveis de fibra oriundo da forragem sobre o consumo e eficiência de utilização de nutrientes em cabras lactantes. Revista Brasileira de Zootecnia, v.39, n.11, p.2477-2485, 2010.

CARVALHO, S.; RODRIGUES, M.T.; BRANCO, R.H. et al. Consumo de nutrientes, produção e composição do leite de cabras da raça Alpina alimentadas com dietas contendo diferentes teores de fibra. Revista Brasileira de Zootecnia, v.35, n.3, p.1154-1161, 2006.
CENKVÀRI, É.; FEKETE, S.; FEBLE, H. et al. Investigation on the effects of Ca-soaps of oil linseed on rumen fermentation in sheep on milk composition of goats. Journal of Animal Physiology and Animal Nutrition, v.89, n.3-6, p.172-178, 2005.

COCHRAN, R.C.; ADAMS, D.C.; WALLACE, J.D. et al. Predicting digestibility diets with internal markes: evalution of four potential markers. Journal of Animal Science, v.63, n.5, p.1476-1483, 1986.

DULPHY, J.P.; DEMARQUILY, C. The regulation and prediction of feed intake in ruminants in relation to feed characteristics. Livestock Production Science, v.39, n.1, p.1-12, 1994.

GRANT, R.J.; ALBRIGHT, J.L. Feeding behavior and amanagement factors during the trasintion period in dairy cattle. Journal of Animal Science, v.73, n.12, p.2791-2803, 1995.

JOHNSON, T.R.; COMBS, D.K. Effects of prepartum diet, inert rumen bulk, and dietary polyethylene glycol on dry matter intake of lactating dairy cows. Journal of Dairy Science, v.74, n.3, p.933-944, 1991.

MERTENS, D.R. Predicting intake and digestibility using mathematical models of ruminal function. Journal of Animal Science, v.64, n.5, p.1548-1558, 1987

MERTENS, D.R. Methods in modelling feeding behavioivaur and intake in herbivores. Annales de Zootechnie, v.45, p.153-164, 1996. (Suppl. 1).

MERTENS, D.R. Physical effective NDF and its use in formulating dairy rations. In: SIMPÓSIO INTERNACIONAL EM BOVINOS DE LEITE, 2., 2001, Lavras. Anais... Lavras: UFLA-FAEP, 2001. p.25.

NATIONAL RESEARCH COUNCIL - NRC. Nutrient requirements of dairy cattle. 7.ed. Washington: D.C.: National Academic Press, 2001. 381p.

NATIONAL RESEARCH COUNCIL - NRC. Nutrient requirements of sheep. Washington: D.C.: National Academic Press, 2007. $362 p$.

PALMQUIST, D.L.; JENKINS, T.C. Fat in lactation rations: review. Journal of Dairy Science, v.63, n.1, p.1, 1980.

PIMENTEL, P.G. Digestão e desempenho de vacas consumindo dietas com castanha de caju. 2007. 95f. Tese (Doutorado em Zootecnia) - Universidade Federal de Minas Gerais, Belo Horizonte.

PIMENTEL, P.G.; MOURA, A.A.A.N.; NEIVA, J.N.M. et al. Consumo, produção de leite e estresse térmico em vacas da raça Pardo-Suíça alimentadas com castanha de caju. Arquivo Brasileiro de Medicina Veterinária e Zootecnia, v.59, n.6, p.1523-1530, 2007.

POLLI, V.A.; RESTLE, J.; SENNA, D.B. et al. Aspectos relativos à ruminação de bovinos e bubalinos em regime de confinamento. Revista Brasileira de Zootecnia, v.25, n.5, p.987-993, 1996.

SILVA, M.M.C.; RODRIGUES, M.T.; RODRIGUES, C.A.F. et al. Efeito da suplementação de lipídeos sobre a digestibilidade e os parâmetros da fermentação ruminal em cabras leiteiras. Revista Brasileira de Zootecnia, v.36, n.1, p.246-256, 2007.

SILVA, D.J.; QUEIROZ, A.C. Análise de alimentos: métodos químicos e biológicos. Viçosa, MG: Editora UFV, 2002. p.235.

SNIFFEN, C.J.; O'CONNOR, D.J.; VAN SOEST, P.J. et al. A net carbohydrate and protein system for evaluating cattle diets: carbohydrate and protein availability. Journal of Animal Science, v.70, n.11, p.3562-3577, 1992.

UNIVERSIDADE FEDERAL DE VIÇOSA - UFV. SAEG - Sistema de análises estatísticas e genéticas. Viçosa, MG: 2000. (CD-ROM).

VAN SOEST, P.J.; ROBERTSON, J.B.; LEWIS, B.A. Methods for dietary fiber, neutral detergent fiber, and nonstarch polyssacharides in relation to animal nutrition. Journal of Dairy Science, v.74, n.10, p.3583-3597, 1991.

VAN SOEST, P.J. Nutritional ecology of the ruminant. Ithaca: Cornell University Press, 1994. p.476. 